University of California, Hastings College of the Law UC Hastings Scholarship Repository

2016 Board of Directors Agenda and Materials

Board of Directors Agenda and Materials

3-4-2016

\title{
Board of Directors Meeting Minutes 03/04/2016
}

UC Hastings Board of Directors

Follow this and additional works at: https://repository.uchastings.edu/board_materials_2016

\section{Recommended Citation}

UC Hastings Board of Directors, Board of Directors Meeting Minutes 03/04/2016 (2016).

Available at: https://repository.uchastings.edu/board_materials_2016/87

This Board of Directors is brought to you for free and open access by the Board of Directors Agenda and Materials at UC Hastings Scholarship Repository. It has been accepted for inclusion in 2016 Board of Directors Agenda and Materials by an authorized administrator of UC Hastings Scholarship Repository. 


\section{UNIVERSITY OF CALIFORNIA HASTINGS COLLEGE OF THE LAW \\ BOARD OF DIRECTORS \\ OPEN SESSION \\ MINUTES}

March 4, 2016 - 9:00 a.m.

UC Hastings College of the Law

Alumni Reception Center, $2^{\text {nd }}$ Floor

200 McAllister Street

San Francisco, California 94102

Chair Thomas Gede called the meeting to order at 9:00 a.m. and the Secretary called the roll.

1. ROLL CALL

Board Members Present

$\underline{\text { Staff Present }}$

2. PUBLIC COMMENT PERIOD
Chair Thomas Gede

Vice Chair Chip Robertson

Director Donald Bradley - via telephone

Director Tina Combs - via telephone (30 min)

Director Marci Dragun

Director Claes Lewenhaupt - via telephone

Director Mary Noel Pepys

Director Sandra Thompson

General Counsel Elise Traynum

Chancellor \& Dean David Faigman

Provost \& Academic Dean Elizabeth L. Hillman

Associate Academic Dean Jeff Lefstin

Chief Financial Officer David Seward

Chief Development Officer Eric Dumbleton

Director of External Relations Alex Shapiro

ASUCH President Nicholas Lansdown

Controller Debbie Tran

Simona Agnolucci

Courtney Power 
Public comments were provided by 3L student Ronnie Shou, noting the significance to her personally of the presence of Department of Safety officers.

\section{REPORT OF ASUCH PRESIDENT}

ASUCH President Nicholas Lansdown summarized recent ASUCH efforts and areas of concerns for students, including the state of the elevators and the desire that the College work with local hotels/motels, so that students' families may have an easier time with accommodations when they visit.

*4. GENERAL CONSENT CALENDAR

Chair Tom Gede announced Provost \& Academic Dean Elizabeth Hillman's decision to become the next president of Mills College. Provost \& Academic Dean Elizabeth Hillman spoke, as did Chancellor \& Dean David Faigman following this announcement.

*4.1 Approval of Minutes: September 11, 2015 and December 4, 2015

4.2 Ratification of Employment Agreement / Acting Chancellor \& Dean

Upon motion duly made, seconded, and carried, the Board of Directors of the University of California Hastings College of the Law approved the General Consent Calendar.

4.3 Resolutions Appointing Simona A. Agnolucci and Courtney Power to the UC Hastings Board of Directors

Chair Tom Gede introduced appointment of the two new Directors to the Board of Directors. He noted that the Governor makes the appointments, the state senate confirms the appointment, and the UC Hastings Board of Directors finally approves the Directors. Upon motion duly made, seconded, and carried, the Board of Directors of the University of California Hastings College of the Law approved the above resolutions appointing Simona A. Agnolucci and Courtney Powers to the UC Hastings Board of Directors.

5. REPORT OF THE CHAIR OF THE EDUCATIONAL POLICY COMMITTEE

\subsection{Initial Assessment of Flexible JD Option}

Provost \& Academic Dean Elizabeth Hillman provided the report on the educational policy committee. She discussed the flexible JD option, researched by BRCOE (Berkeley Resource Center for Online Education). BRCOE was then asked to do more in-depth research into a flexible JD program. Their subsequent in-depth study was not so positive with regard to the market, but it was positive on the market for a master's of studies in law that would be a compressed, flexible degree. Chancellor \& Dean David Faigman spoke to the benefits of an MSL program as a power complement to a number of technical and scientific degrees. Provost \& Academic Dean Elizabeth Hillman and 
Chancellor \& Dean David Faigman both spoke at length about the high demand for online courses and the anticipated roll-out of a flexible JD program.

\subsection{Admissions and Retention Plans}

Provost \& Academic Dean Elizabeth Hillman discussed admissions and retention plans. She noted that it is difficult to know prior to the deposit deadlines in April the status of the incoming class, and highlighted the priority of improving class metrics.

\subsection{Update on Bar Passage Efforts}

Provost \& Academic Dean Elizabeth Hillman presented slides on bar passage. She noted the Bar exam will be changing to a 2-day version in 2017. She reported on the expansion of critical studies courses and of orientation. She noted that Associate Academic Dean Jeff Lefstin is meeting with students whose performance has lagged in order to get them specialized help. Those students are provided access to the academic support program. Chancellor \& Dean David Faigman then spoke at length about ideas under consideration for curriculum reform. He noted these considerations would be thoroughly discussed and voted on at an upcoming faculty retreat.

\subsection{Update on Library and Technology Reorganization}

Provost \& Academic Dean Elizabeth Hillman announced the recruitment of a new library director, Camillla Tubbs, who is coming from the University of Maryland and will be starting this summer.

5.5 Provost and Academic Dean Report on Informational Items, Including Academic Programs and Student Services

\section{REPORT OF THE CHAIR OF THE ADVANCEMENT \& COMMUNICATIONS COMMITTEE}

Director Sandra Thompson introduced the report of the Advancement \& Communications Committee.

*6.1 Resolution Amending Standing Order 100.4 (m)(2), Granting Authority to the Chancellor \& Dean to Accept Gifts to the College of $\$ 100 \mathrm{~K}$ or Less in Lieu of the UC Hastings Board of Directors

Chief Development Officer Eric Dumbleton introduced Albert Abramson Professor Leo Martinez, who presented the resolution amending standing order $100.4(\mathrm{~m})(2)$. He noted it was discussed in the committee meetings and it was the consensus that the increased amount was necessary.

6.2 Report of Albert Abramson Professor Leo P. Martinez, Chair of the 333 Golden Gate Capital Campaign: 
6.2.1 Resolution Establishing the "Building UC Hastings Fund"

6.2.2 Resolution Fast-Tracking the Gift Acceptance Process

6.2.3 Resolution Regarding the Naming of UC Hastings Properties, Programs, and Facilities Procedures

Albert Abramson Professor Leo Martinez described the resolutions above, noting they are interrelated. The combined purpose is to establish a receptacle for the receipt of capital funds, to allow for fast-track acceptance of gifts, and to establish suggested minimums for naming opportunities of various parts of the new building. Some discussion ensued about the application and significance of these changes.

Upon motion duly made, seconded, and carried, the Board of Directors of the University of California Hastings College of the Law approved the above resolutions.

Chief Development Officer Eric Dumbleton articulated a number of changes on the fundraising front, including staffing and pipeline management. He noted he eliminated the managing director of development position and replaced that with a director of alumni engagement. He also discussed changes in internal focus and increased aggression in fundraising efforts. Ideas for fundraising events were also highlighted. Chief Development Officer Eric Dumbleton then enumerated the below reports, highlighting the key points in each. The Board further discussed ways to improve and nurture donor relations throughout the capital campaign.

Director of External Relations Alex Shapiro also spoke about donor opportunities and the rolling out of a "brick-by-brick campaign," an idea he credited to Chancellor \& Dean David Faigman. He noted that the College's ranking among lawyers and judges is number 19 and elaborated at length on rankings and the factors that influence the school's ranking. The importance of building strong media relations was also discussed at length. Director of External Relations Alex Shapiro emphasized that the goal of the campaign is to reestablish UC Hastings as a top 20 school in the U.S. News rankings, highlighting recent successes, including that of the UC Hastings Trial Team in the recent annual national competition.

6.3 Cy Pres Gifts

6.4 \$100K + Gifts \& Pledges

6.5 Realized Planned Gifts

6.6 Fundraising Comparison Raised Report

6.7 Fundraising Comparison Received Report

6.8 Year-to-Date Gifts Comparison Report

*7. FINANCE COMMITTEE CONSENT CALENDAR 


\section{*7.1 State Budget Report as of December 5, 2015 and Mid-Year Budget Changes}

Chief Financial Officer David Seward provided the summary of the state budget report. He noted some erosion on the revenue side, with targets not being met for the LLM and MSL programs. He noted non-resident tuition did better than other categories. However, he reported the budget gap was successfully narrowed, and the overall deficit was reduced from \$3.6 million to \$2.4 million, primarily through salary savings and through under-awarding of financial aid grants. He reported the total cash flow from all auxiliary enterprises to be $\$ 1.9$ million. He also noted anticipated cost growth ahead, with many labor agreements expiring in the next fiscal year and the need to address compensation policies for non-represented employees. He reported the governor's decision to allocate $\$ 2$ million in the upcoming budget for purposes of funding deferred maintenance to be a source of relief which allowed the College to defer until next year certain maintenance activities that had been planned for this year.

Upon motion duly made, seconded, and carried, the Board of Directors of the University of California Hastings College of the Law approved the Mid-Year Budget Changes.

*7.2 State Contracts in Excess of \$50,000

7.2.1 Software License Agreement - SpringCM

7.2.2 Library Subscription - Thomson Reuters (Westlaw)

*7.3 Auxiliary Enterprises Budget Report as of December 31, 2015 and Mid-Year Budget Changes

*7.4 Auditor Selection - Auditor Selection Committee Recommendation

Director Tina Combs introduced the report on auditor selection. Controller Debbie Tran began with a history of the relationship with Hood \& Strong, extending back thirteen years, noting that a change is in order. She noted seven firms were invited and elaborated at length on the selection process. She noted they were particularly impressed with Moss-Adams, who were unanimously selected. Controller Debbie Tran elaborated on the expertise of Moss-Adams and the many reasons they would serve the College well. Questions of potential conflict of interest were raised and resolved. It was agreed that transition planning would begin and that the engagement letter and timeline would be submitted to the finance committee at the next meeting.

Upon motion duly made, seconded, and carried, the Board of Directors of the University of California Hastings College of the Law approved the selection of Moss-Adams as auditor.

*7.5 Nonstate Contracts in Excess of \$50,000

7.5.1 Security Services - 100 McAllister Tower

*7.6 Nonstate Budget Changes

7.6.1 Long-Range Campus Plan

*7.7. Endowment Management - Spending Rate for 2016-17

*7.8 Student Housing - Residential Rent Increases for 2016-17 


\section{REPORT OF THE CHIEF FINANCIAL OFFICER}

\section{*8.1 UC Office of Home Loans-Mortgage Origination Program (MOP)}

Chief Financial Officer David Seward first recalled the Board's authorization of participation in the University of California home loan program last fall, which was conditioned on final approval of the agreement. He noted the program is underway, that feedback has been extremely positive, and that the program is benefiting the College.

Upon motion duly made, seconded, and carried, the Board of Directors of the University of California Hastings College of the Law approved the Mortgage Origination Program.

*8.2 State Contracts Over \$50,000

8.2.1 Kane Hall Repurposing Project - Mkthink

8.2.2 Environmental Services - TRC

Chief Financial Officer David Seward presented contracts over \$50,000. He provided an update on the CEQA consultation and analysis for the long-range campus plan, and he reported on wind mitigation measure studies and shadow analyses. It was clarified that the state grant for the 333 Golden Gate building does not include the CEQA review. Chief Financial Officer David Seward noted that the CEQA document is being reviewed by a top land use lawyer, Charles Olson.

Upon motion duly made, seconded, and carried, the Board of Directors of the University of California Hastings College of the Law approved the above state contracts in excess of $\$ 50,000$.

8.3 Investment Report as of December 31, 2015

8.4 State Budget Update - Governor's Budget for 2016-2017

8.5 Recommendations on Payroll and HR Policies and Procedures

8.6 Long-Range Campus Plan - Draft Environmental Impact Report

8.7 Governor's Renewable Energy Mandate - Solar Power Evaluation

8.8 Report on Faculty and Staff Salaries Over \$100,000

8.9 List of Checks Over \$50,000

Chief Financial Officer David Seward summarized the remaining informational items, including the governor's budget for 2016-17.

\section{REPORT OF THE CHAIR}

9.1 Appointment of Director Simona A. Agnolucci and Courtney Power to Board Standing Committees

10. REPORT OF THE CHANCELLOR \& DEAN

\subsection{Chancellor \& Dean’s Report}


Chancellor \& Dean David Faigman spoke at length about possible collaborations and partnerships to be explored moving forward. He elaborated on a number of meetings and contacts he is pursuing at UCSF and elsewhere in the interest of developing future collaborations and partnerships, and he expressed optimism in the College's growth. He also spoke about the upcoming release of the U.S. News rankings and actions he is taking to prepare for their release and to respond to them.

\subsection{Report on Recommended Payroll and Human Resources Policies by Moss Adams Consulting}

Steve Fineberg from Moss-Adams Consulting summarized the report on recommended payroll and Human Resources Policies. He highlighted the importance of matching up intended outcome with actual outcome. He also noted the importance of explicit policies that outline procedures for certain activities, including stipends, pay adjustments, settlements, promotions, and reclassifications, and that such policies should be consistently applied over time. Finally, he spoke about budgets as a tool that controls expectations, and how automated reports can be used to highlight changes for immediate review and authorization. Extensive discussion over internal controls and the findings of the study ensued. Mary Case from Moss-Adams Consulting further noted that the challenge observed was in executing policy and interpreting it, rather than in finding an applicable policy.

10.3 Report on Action Taken in Closed Session Regarding Gifts and Appointments

10.4 Other Informational Items: Academic Programs, Student Services, External Relations and Personnel

\section{REPORT OF THE GENERAL COUNSEL}

*11.1 Request to Set New Date for the June Board of Directors Meeting 11.2 Report on 2016 Board of Directors / Faculty Retreat

General Counsel Elise Traynum presented the request to set a new date for the June Board of Directors meeting and discussed the annual faculty board retreat.

12. Director Comments and Board Announcements

13. The Board will go into closed session at approximately 11:00 a.m.

14. Adjournment

There being no further business to come before the Board of Directors, the Open Meeting was adjourned at approximately 12:30 a.m.

Respectfully submitted, 
Elise K. Traynum, Secretary 